\title{
THE DISTRIBUTION OF LEGISLATIVE COMPETENCES BETWEEN STATE AND REGIONS IN THE EVOLUTION OF THE ITALIAN CONSTITUTIONAL COURT CASE LAW
}

\begin{abstract}
The article deals with the issue of the distribution of legislative competences between the State and the Regions after the reform of Title V of the Italian Constitution (1999-2001). After setting out the novelties introduced by the reform and, in particular, the contents of the "new" Section 117 of the Constitution, the Author focuses both on the contribution of constitutional case-law to the correct definition of state and regional competence areas and on the decision-making techniques implemented. The case-law examination highlights the constant tension between the autonomist and the unitary claims and the need to promote dialogue and cooperation between the State and the Regions to overcome the current conflict, hence ensuring the good functioning of the Italian regional system.
\end{abstract}

\section{Keywords}

Italian regional system - legislative powers - distribution of competences

* Dr Lino Panzeri, Associate Professor, Insubria University; lino.panzeri@uninsubria. it. The Author is a Researcher at the Insubria University, where he teaches Elements of Public Law. His research is mainly focused on the Italian regional law, the constitutional justice and the protection of linguistic rights. His publications include (with Giuseppe D'Elia), Statuti ordinari e legge regionale. Contributo allo studio del giusto procedimento legislativo, 


\section{INTRODUCTION}

The Italian regional model introduced by the Constitution, which came into force in 1948, has been implemented in a slow and discontinuous way. Indeed, over the decades, there has been a constant tension between the unifying efforts of the central State and the autonomy claims of the Regions (especially of the richest ones), which even the deep reform of Title V (1999-2001) has failed to resolve. The modified distribution of the legislative competences between the State and the Regions (Section 117 of the Italian Constitution), which formally expanded regional autonomy, has generated interpretative uncertainty, determined both by the imprecision of certain choices of the constitutional legislator and by the lack of adequate tools of connection between state and regional levels.

Although the Constitutional Court offered a decisive exegetical contribution, on which this essay focuses, the reform did not overcome the tension between the State and the Regions. Therefore, the awareness of this limit in recent years has suggested the opportunity of a new constitutional reform, aiming at seeking a more stable balance between the two levels of government. Adopting this reform, however, continues to be the object of a difficult political confrontation.

\section{THE Distribution OF COMPETENCES BETWEen StATE and Regions in TitLe V of the ItALIAN Constitution}

During the drawing up of the Republican Constitution, the Constituent Assembly spotted territorial pluralism as one of the fundamental characteristics of the new democracy and, in consistency with this premise, provided for the creation of Regions and granted them legislative functions.

In the constitutional text originally approved, the distribution of powers was characterized by the reserve to the central State of an exclusive and general legislative competence, which was only limited

Franco Angeli, Milano, 2012, and La tutela dei diritti linguistici nella Repubblica delle autonomie, Giuffrè, Milano, 2016. 
with respect to those subject-matters which even the ordinary Regions could legislate pursuant to Section 117 of the Constitution. However, this regional competence was limited in that it concerned less important matters and was not exclusive but rather concurrent: the Regions were in fact bound to respect the fundamental principles dictated by the State; therefore, the relative autonomy was limited to the legislation of details. The condition of Italian special Regions (Aosta Valley, Trentino-High Adige, Friuli-Venezia Giulia, Sicily and Sardinia) was definitively more favorable: their autonomy was defined by their own Statutes (approved by constitutional law), which ascribed to each of these Regions different legislative powers, sometimes even exclusively, in a list of predefined subject-matters.

The implementation of the regional model provided by the Constitution, at least to the ordinary Regions - which were only created in 1970 - was slow and partial. The possibility to legislate only within the limits of the fundamental principles dictated by state legislation reflected negatively on territorial legislative activities. On the one hand, even when it took measures through special "framework laws" for the definition of principles, the State often even ended up dictating detailed rules to the whole Country unless the single Region had already exercised its competence. On the other hand, the model introduced by the Constituent Assembly contributed to create conflictual relations between State and Regions, often pushing each of them, according to the procedure provided for by Section 127 of the Constitution ${ }^{2}$, to contest each other's rules before the Constitutional Court. The latter was thus called upon to define the various areas of competence.

After this initial model, the Italian Parliament started a process aimed at strengthening the self-government system during the 1990s. The process was initially carried out at an administrative level (see Law no. 59 of 15 March 1997, the so-called "Bassanini Law") and later, between 1999 and 2001, implemented through direct amendments to the Constitution ${ }^{3}$.

2 See below, Par. III.

${ }^{3}$ See Constitutional Law no. 1 of 22 November 1999 ("Provisions concerning the direct election of the President of the Regional Executive and the statutory autonomy of the Regions"); Constitutional Law no. 2 of 31 January 2001 ("Provisions concerning the direct election of the Presidents of the special Statute Regions and the autonomous Provinces 
Constitutional Law no. 3/2001, in particular, amended many articles of Title V, including Section 117 of the Constitution, thus defining a new system of distribution of competences between State and Regions ${ }^{4}$.

Paragraph 2 reserves to the exclusive competence of the State a list of supra regional subject-matters, whose regulation serves unitary interests; this list includes, for example: "state foreign policy and international relations" (letter $a$ ), "defense and armed Forces" and "state security" (letter $d$ ), "currency" (letter $e$ ), "citizenship" (letter i), "customs" (letter q). Paragraph 3 includes a list of subject-matters (expanded if compared to the previous Section 117) of concurrent regional competence, "except for the determination of the fundamental principles", which is reserved to the State. Paragraph 4, through a residual clause, reserves every subjectmatter which is not listed in Paragraphs 2 and 3 (purposely defined as "un-named" subjects) to the legislative autonomy of the Regions (residual competence).

The above Constitutional Law further introduced the so-called "more favorable clause" for special Regions. This clause provides that "the rules allowing for broader autonomy" set out in the new constitutional provisions also apply to special Regions until their Statutes are amended accordingly. The above Constitutional Law also amended Paragraph 3 of Section 116, thus admitting the acknowledgement of some forms of differentiation on a regional basis. The rule provides that, following a compounded legislative process, the Regions can be granted "special additional forms and conditions of autonomy" in every subject-matter which belongs to their concurrent competence and, with respect to state exclusive competences, in the following subject-matters: "jurisdiction and procedural law" (but only for "the operation of justices of peace"), "general provisions on education" and "protection of the environment, the ecosystem and the cultural heritage".

From a descriptive point of view, the 2001 constitutional amendment, inspired by the experience of more traditional federal systems, seemed

of Trento and Bolzano"); Constitutional Law no. 3 of 18 November 2001 ("Amendments to Title V of Part II of the Constitution").

${ }^{4}$ In the exercise of their legislative powers, State and Regions are now equally required to comply with both the Constitution and the "EU and International obligations" (Section 117, Paragraph 1, of the Constitution). 
to have significantly expanded the legislative autonomy of the Regions, identifying the latter, instead of (as previously) the State, as the holders of a "general legislative competence".

However, this assumption was promptly reappraised by scholars by simply considering the letter of the legislation.

First of all, the subject-matters reserved to the State, although officially listed, are numerous and broad (the State is reserved, inter alia, the regulation of "jurisdiction", "procedural law" and "civil and criminal law") $)^{5}$, as well as those referred to concurrent competence. This downsizes regional competence, emptying the meaning of the residual clause set out in Paragraph 4 and thus refuting the proposition according to which the Regions, and not the State, would acquire "general legislative competence".

In some cases, then, the same subject-matter is divided into several areas of competence. It is the case, for example, for the environment, which is reserved to the State as for the "protection of the environment, the ecosystem and the cultural heritage" (Section 117, Paragraph 2, letter s). On the contrary, the "enhancement of environmental assets" falls within the concurrent competence of State and Regions; it is also the case for education, which is reserved to the State with regard to its "general provisions" (Section 117, Paragraph 2, letter $n$ ), while "education, except for the autonomy of educational institutions and vocational education and training" falls within concurrent competence.

This "fragmentation" itself is conflictual because it makes harder to identify the limits of legitimate state and regional intervention.

Moreover, it is sometimes hard to define the contents of the areas of competence themselves, which are not related to a specific subjectmatter but merely set a goal, the realization of which ends by easing the allocation of the competences defined by Section 117 of the Constitution.

This is the case, in particular, for the so-called "transversal" competences, already so defined by the doctrine ${ }^{6}-$ including, in addition

5 These choices, already on a formal level, tend to limit the areas of competence referred to the Regions if compared to state ones: see F. Giuffrè, Unità della Repubblica e distribuzione delle competenze nell'evoluzione del regionalismo italiano [Unity of the Republic and distribution of competences in the evolution of Italian regionalism], Torino 2012, p. 90-91.

${ }^{6}$ G. Falcon, Il nuovo Titolo $V$ della parte seconda della Costituzione [The new Title V of Part II of the Constitution], "Le Regioni” 2001, no. 1, p. 5. 
to the already mentioned "protection of the environment, the ecosystem and the cultural heritage" (letter $s$ ), the "competition protection" (letter $e$ ) and the "determination of the basic levels of benefits relating to the civil and social entitlements to be guaranteed throughout the national territory" (letter $m$ ) -, the exercise of which is bound to overlap or interlace with other areas of regional competence, both concurrent and residual ${ }^{7}$.

In rewriting Section 117 of the Constitution, Constitutional Law no. 3/2001 also omitted any reference to certain typically "federal" subject-matters, such as "post and telecommunications" and "road traffic" $^{\prime 8}$. The final version of the text even moved the competence on several subject-matters from one list to another (this is the case, for example, for "national production, transport and distribution of energy", which was moved from the list of state exclusive competence to that of concurrent one), thus making choices with unforeseeable consequences in terms of satisfaction of the unitary interests expected by the exercise of such competence ${ }^{9}$.

Perplexity was also raised by the renewed concurrent competence with regard, in particular, to the definition of the principle/detail ${ }^{10}$ relationship - and also by the same category of residual competence, both for the uncertain meaning of "exclusivity" and, because of its "unnamed" peculiarity, for the difficulties related to its identification ${ }^{11}$.

Since the entry into force of Constitutional Law no. 3/2001, the just mentioned remarks led scholars to heavily rely on the Constitutional

7 See below, Par. IV.1.

${ }^{8}$ On these gaps see A. D'Atena, Materie legislative e tipologia delle competenze [Legislative subject-matters and types of competences], "Quaderni costituzionali" 2003, no. 1, p. 16 et seq.

9 See U. De Siervo, Intervento [Intervention], [in:] G. Berti, G.C. De Martin (a cura di), Le autonomie territoriali: dalla riforma amministrativa alla riforma costituzionale [Territorial autonomies: from the administrative to the constitutional reform], Milano 2001, p. 77.

${ }^{10}$ See below, Par. IV.3.

11 On residual competences, among the first essays, see L. Torchia, La potestà legislativa residuale delle Regioni [The residual legislative power of Regions], „Le Regioni” 2002, no. 2-3, p. 343 et seq.; more recently, see S. Parisi, La competenza residuale [The residual competence], „Le Regioni" 2011, no. 2-3, p. 341 et seq., and G. Cosmelli, Oltre i confini della "materia". La potestà legislativa residuale delle Regioni tra poteri impliciti e sussidiarietà [Beyond the boundaries of "subject-matters". The residual legislative power of the Regions between implied powers and subsidiarity], Milano 2015. 
Court for clarifications ${ }^{12}$. The latter was indeed called upon in later years to play a fundamental role in the interpretation of the law by identifying the areas of competence of each legislator (State or Regions) and the unifying elements of the system, which can ensure relative sustainability, even in a context of greater differentiation on a territorial basis.

\section{THE JUDICIAL TOOLS FOR THE GUARANTEE OF PLURALISM: „JUDGMENT BY PRINCIPAL WAY”}

Before analysing the constitutional case law on the new Title V and its contribution to defining the exact competence framework, we should consider, though incidentally, that Constitutional Law no. 3/2001 amended not only Section 117 but also Section 127 of the Italian Constitution, thus changing the process of constitutional control of laws "by principal way", which allows the State and the Regions to ensure protection of their legislative powers.

In its old text, Section 127 allowed the State to control regional legislative resolutions before their final approval. In particular, if the Government found any excess of regional competence or any conflicts between regional resolutions and national interests or the interests of any other Regions, it could ask the Regional Council to review any such resolutions. In case of re-approval by absolute majority of the members of the Council, the Government could raise an issue of constitutional legality before the Constitutional Court ${ }^{13}$. However, Section 2 of Constitutional

12 According to L. Ronchetti, The Judicial Construction of Italian Regionalim, [in:] S. Mangiameli (ed.), Italian Regionalism: Between Unitary Traditions and Federal Processes. Investigating Italy's Form of State, Essays on Federalism and Regionalism 1, New York 2014, p. 380: "It might be said that without the contribution of Constitutional Court case law, the revised relations between the State and Regions enacted in Constitutional Law no. 3 of 2001 would have largely remained a dead letter".

${ }^{13}$ In case of re-approval of the text, the previous Section 127 also allowed the Government to raise an issue on the merits (due to any conflicts with national interests or the interests of any other Regions) before the Chambers of the Italian Parliament; however, this issue was never raised by the Government. In general, on the question of preventive control on regional laws before Constitutional Law no. 3/2001, see L. Paladin, Diritto regionale [Regional Law], Padova 2000, p. 400 et seq. 
Law no. 1/1948 allowed the Regions to challenge state laws (or state acts having the force of law $)^{14}$, but only if they deemed that their own area of competence had been invaded and only after their approval within thirty days of publication in the Official Journal. This system, however penalizing the Regions vis-à-vis the State, made it possible to identify any possible conflicts beforehand, because the reviewed text became the object of a pre-action confrontation between the Government and every single Region, which often ended on a political level with the acceptance of state recommendations by the Regional Council.

Today, in any case, the check on laws "by principal way" is always subsequent, because both the Government - "when it finds that a regional law exceeds regional competence" - and the Regions - "when they find that any state or regional laws or acts having the force of law fall within their purview of competence" - may challenge such laws or acts within sixty days of their publication.

The equalization of time-limits for legislative control ${ }^{15}$ satisfies the requirement of equalizing the condition of the State with that of the Regions as constituent entities of the Republic with equal dignity (Section 114, Paragraph 1, of the Italian Constitution). On the other hand, this model eliminated preventive checks on regional legislation ${ }^{16}$, which, though seriously faulty, can now come into force in any case because the Government can only challenge it at a later time ${ }^{17}$.

${ }^{14}$ Section 2 required, for this purpose, a special resolution by the Regional Executive.

15 Although Section 127 of the Constitution could imply the equalization of the regional with the state action also with respect to objectionable defects, the Constitutional Court (Judgment no. 274/2003) ruled out this possibility; so, while the Government can challenge regional laws complaining about their violation of constitutional provisions, Regions can only challenge state laws if they are deemed to encroach upon their area of competence.

${ }^{16}$ See E. Gianfrancesco, Il controllo sulle leggi regionali nel nuovo art. 127 [The control over regional laws in the new Section 127], [in:] T. Groppi, M. Olivetti (a cura di), La Repubblica delle autonomie. Regioni ed enti locali nel nuovo Titolo $V$ [The Republic of autonomies. Regions and local authorities in the new Title V], Torino 2001, p. 131.

${ }^{17}$ Awareness of this limit led Regional Councils, upon approval of their new Statutes, to provide for the so-called "Organs of statutory guarantee", which, although institutionally responsible for ensuring "statutory rigidity", also seem entitled to intervene in case of constitutional violations, by "burdening" the various legislative processes set out in each regional Statute: see G. D’Elia, L. Panzeri, Statuti ordinari e legge regionale. Contributo allo 
The renewed procedural system, in addition to the reformed (and, as mentioned, problematic) table of competences, inevitably led to an exponential growth in litigation ${ }^{18}$, that brought before the Constitutional Court not only matters having an adequate constitutional "tone" but also irrelevant issues that would (or should) have found a better definition on a preventive political level.

\section{THE CONTRIBUTION OF CONSTITUTIONAL CASE LAW TO THE DEFINITION OF STATE AND REGIONAL AREAS OF COMPETENCE}

As stated above, although the ambiguity of Section 117 of the Italian Constitution, the extension of regional legislative powers and the disappearance of preventive checks on regional laws by the Government imposed upon the Constitutional Court the uneasy role of "judge of pluralism"; the latter, despite some uncertainties in construction and not infrequent revirement, has been able to offer a decisive exegetical contribution.

This contribution, first of all in terms of method, was able to limit the consequences of uncritical qualifications of regional laws, compared to state ones, as source having "general competence", bound to spread into every area unrelated with Section 117, Paragraphs 2 and 3, of the Constitution.

If, indeed, the Constitutional Court initially suggested starting "not so much from the research of a specific constitutional title for regional action, but, on the contrary, from the investigation into the existence of exclusive or partial levels of state competence" (Judgment no. 282/2002) and, again, established the existence of state legislative powers "only where it was possible to infer a specific title of legitimacy from the Constitution" (Judgment no. 1/2004), soon the Court judges moved

studio del giusto procedimento legislativo [Ordinary Statutes and regional law. Contribution to the study of the proper legislative process], Milano 2012, p. 95-111.

${ }^{18}$ For example, if in 2002 the decisions taken at the end of judgments raised by principal way accounted for 5,59\% of the total, in 2013 this percentage reached $45,70 \%$. 
towards different conclusions, more consistent with the complexity of the relevant constitutional framework. Judgment no. 370/2004 already set out that regional competence (in this case, the residual one) does not exist "for the mere fact that this subject-matter is not readily attributable to any of the titles listed in Section 117, Paragraphs 2 and 3, of the Constitution", thus leading to relativize the same coincidence between the "competence" of a source and the "reserve of rule" of the same ${ }^{19}$.

Constitutional case law, adopting this very formalistic approach, contributed to better defining the titles of competence, even by filling the above-mentioned gaps: this happened, for example, with regard to "road traffic", which, although not included, as mentioned above, in the lists of Section 117, Paragraphs 2 and 3, of the Constitution, has been properly attributed, through interpretation, to exclusive state competence ${ }^{20}$.

In other cases, the Constitutional Court put into the concurrent competence category some hardily classifiable subject-matters such as, for example, "town-planning" and "building", which were subsumed, in the absence of any constitutional provision, into "land-using planning" ${ }^{21}$. Again, with regard to subject-matters falling under the "residual" competence category, some decisions allowed their identification, for example, with "agriculture" 22, "craft" 23 , "trade" 24 , "social services and policies" 25 , "regional transport" 26 , "local public services" 27 or, again, with the regulation of "mountain Communities"28.

However, the Constitutional Court played its most significant exegetical role in the cases where the object of a law could be associated with more subject-matters, especially with different rules of competence.

19 See F. Modugno, La posizione e il ruolo della legge statale nell'ordinamento italiano [The position and role of state law in the Italian legal system], May 2006, available at: www.issirfa. cnr.it [last accessed: 06.05.2017].

${ }^{20}$ See Judgment no. 428/2004.

${ }^{21}$ See Judgments no. 362/2003, no. 196/2004 and no. 232/2005.

22 See Judgment no. 12/2004.

${ }^{23}$ See Judgment no. 162/2005.

${ }^{24}$ See Judgments no. $1 / 2004$ and no. 64/2007.

${ }^{25}$ See Judgments no. 287 and no. 423/ 2004.

26 See Judgment no. 222/2005.

27 See Judgment no. 29/2006.

${ }^{28}$ See Judgment no. 244/2005. 
In Judgment no. 50/2005, the constitutional Judge qualified this event as "competition of competences" and, in acknowledging the absence, in the Italian Constitution, of criteria for overcoming these "interferences", ruled that it was necessary to define new ones.

To that effect, we should first of all quote the prevalence criterion, which provides as follows: if the content of a law can be associated with more subject-matters at the same time, we should establish to which of them this content (or, better, this "core") can be primarily subsumed and, therefore, which authority is competent to legislate ${ }^{29}$.

One of the first decisions to have used this technique is Judgment no. $370 / 2003$ on a rule on kindergartens. By rejecting the arguments of the applicant Regions, the Constitutional Court excluded that this subjectmatter could fall into the regional residual competence category, ruling that "undoubtedly, according to the prevalence criterion, the regulation of that subject-matter may only fall within the scope of education [...], as well as, in some respects, of employment protection, a subject-matter which falls within the scope of legislative concurrent powers under Section 117, Paragraph 3". This trend has been confirmed by many following decisions, including Judgments no. 50/2005 (on training agreements), no. 181/2006 (on health organization), no. 52/2010 (on financial derivates) and no. 183/2012 (on fuel distribution plants). In this last decision, the Constitutional Court rejected the argument of the applicant, according to which the regulation of fuel distribution plants should fall within the scope of residual competence on "trade"; the regulation at issue, in fact, "prevalently falls within the scope of concurrent competence on the distribution of energy (Section 117, Paragraph 3, of the Constitution)" or can be subsumed into other areas of competence however "not related with trade", proving the "recessive nature" of this competence.

Sometimes, however, where the interlacing of competences was particularly complex and it was impossible to establish the prevalence of a subject-matter over another, the prevalence criterion proved inadequate. In these cases, the Constitutional Court made use of the principle of loyal collaboration, which "forces state law to provide adequate tools for the

${ }^{29}$ On the application of this criterion see M. Carrer, Il legislatore competente. Statica e dinamica della potestà legislativa nel modello regionale italiano [The competent lawmaker. Statics and dynamics of legislative powers in the Italian regional model], Milano 2012, p. 135 et seq. 
involvement of Regions" (Judgment no. 219/2005). This is the case, for example, with Judgment no. 168/2009, through which the Court ruled out the constitutional illegality of the state rule providing support for the Observatory against paedophilia and juvenile pornography. After rejecting the claimed infringement of the residual competence on "social policies" and after recalling the state exclusive competences on "public order and security" and "criminal law", this decision confirmed the existence of "an overlapping of competences assigned by the Constitution to both State and Regions which warrants - as it is impossible to affirm the prevalence of a subject-matter over another - the use of the principle of loyal cooperation" 30 , calling for the necessary involvement of the Regions.

\subsection{THE INCIDENCE OF THE SO-CALLED „TRANSVERSAL” SUBJECTS BETWEEN GUARANTEE OF PLURALISM AND FILFILLMENT OF UNITARY REOUESTS}

The over mentioned decision-making techniques generally involve subject-matters whose contents can be distinctly recognized with objective criteria.

However, constitutional case law, acknowledging the first doctrinal remarks on the renewed Section 117 of the Constitution, also accounted for the existence of areas of competence - especially state and exclusive ones - which do not correspond to any specific subject-matter ${ }^{31}$ but rather to an end, purpose and goal, the achievement of which may imply recourse to regional concurrent or residual competences, thus transversally altering the normal distribution of powers ${ }^{32}$.

${ }^{30}$ On the use of the principle of loyal cooperation, see also Judgments no. 234/2005, no. 24 and no. 201/2007, no. 50/2008, no. $278 / 2010$ and no. $33 / 2011$.

${ }^{31}$ Therefore, the doctrine coined the term "dematerialization of subject-matters": F. Benelli, La "smaterializzazione" delle materie. Problemi teorici e applicativi del nuovo titolo $V$ della Costituzione [The dematerialization of subject-matters. The theoretical and application problems of the new Title V of the Constitution], Milano 2006, p. 85.

32 On "transversal" subject-matters, among the first essays, G. Scaccia, Le competenze legislative sussidiarie e trasversali [Subsidiary and transversal legislative competences], „Diritto pubblico" 2004, no. 2, p. 461 et seq., and G. Arconzo, Le materie trasversali nella giurisprudenza della Corte costituzionale dopo la riforma del Titolo $V$ [The transversal subject- 
Since its first decisions following the 2001 constitutional reform, the Court included in these subject-matters the "determination of the basic levels of benefits relating to civil and social entitlements to be guaranteed throughout the national territory" (the so-called LEP) listed in Section 117, Paragraph 2, letter $m$, specifying how this title is not, "literally speaking, a 'subject-matter'", but rather "a state competence which involves all the subject-matters, which must be regulated by the State itself in such a way as to ensure that everyone, in the whole Country, can enjoy the guaranteed benefits" (Judgment no. 282/2002) ${ }^{33}$. The Court also subsumed into this category other subject-matters such as the "protection of the environment" - which was initially refused the qualification as a "'matter' in a technical sense" (Judgment no. 407/2002) 34 $^{34}$ but has been recently given an opposite interpretation (Judgment no. $104 / 2008)^{35}$ - and the "competition protection": the constitutional Judge highlighted "its dynamic nature", specifying how this competence "is not strictly speaking a subject-matter, but rather a 'function' exercisable on many different objects" (Judgment no. 14/2004) ${ }^{36}$. Over the years, the Constitutional Court has also recognized the "expansive" nature of

matters in constitutional case-law after the reform of Title V], [in:] N. Zanon, A. Concaro (a cura di), L'incerto federalismo. Le competenze statali e regionali nella giurisprudenza costituzionale [Uncertain federalism. State and regional competences in the constitutional case-law], Milano 2005, p. 181 et seq.; more recently, F. Bocchini, La trasversalità delle competenze legislative regionali nella Costituzione [The transversal nature of regional legislative competences in the Constitution], Roma 2015.

${ }^{33}$ See also, among others, Judgments no. 322/2009, no. 207/2012 and no. 111/2014.

34 The Court held that the protection of the environment "does not seem to fall under state competence because, on the contrary, it concerns and is inextricably interlaced with other interests and competences"; therefore, the environment is defined "as a constitutionally protected 'value', which, as such, outlines a kind of 'transversal' subject-matter, which includes different competences, that may as well be regional, with the State having to ensure uniform rules on the matter throughout the Country".

35 This decision expressly rejects the argument put forward by the applicant Regions, i.e. "the environment is not a matter in a technical sense"; the Court, while confirming the "transversal" nature of environmental protection - because of the various interests, also falling within regional competences, it involves -, qualifies the "unitary rule of protection of the whole environment" as a subject-matter reserved to state exclusive competence.

36 On the "transversal" nature of "competition protection" see, inter alia, Judgments no. $401 / 2007$, no. $288 / 2010$, no. $150 / 2011$, no. 18 and no. $291 / 2012$. 
other state exclusive competences (including "state foreign policy and international relations" and "relations between the State and the European Union" 37 , "defense" 38 , "civil law"39, "criminal law"40) or concurrent ones (including "professions" 41 , "co-ordination of public finance" 42 , "scientific research" ${ }^{43}$ ), thereby confirming the impossibility to define the areas of competence in terms of strict separation ${ }^{44}$.

The fact that the object of these subject-matters may not be determined beforehand, but only through its exercise, involves that the relationship with regional competences cannot be defined by formally attributing a competence under Section 117 of the Constitution but only on a time by time basis, therefore without being able to establish the degree of interference between the state and the regional source beforehand. Therefore, in the case of transversal subject-matters, it is up to the State to determine the necessary degree of interference to achieve the established goal $^{45}$, which may go so far as to affect the regional competences. In this sense, in Judgment no. 62/2005 (concerning the protection of the environment), the Court, while acknowledging that also the Regions, in the exercise of their powers (for example with respect to "health" and "territorial government"), can achieve the purpose of environmental protection, held that "this does not mean that the State must necessarily limit itself [...] to establishing rules of principle, always making room for further regional legislation".

\footnotetext{
37 See Judgment no. 239/2004.

38 See Judgment no. 431/2005.

39 See Judgments no. 380/2004 and no. 233/2006.

${ }^{40}$ See Judgment no. 185/2004.

${ }^{41}$ See Judgment no. 222/2008.

${ }^{42}$ See Judgment no. 414/2004.

${ }^{43}$ See Judgments no. 423/2004, no. 31/2005 and no. 133/2006.

${ }^{44}$ On the competence titles whose "expansive" nature was recognized by the Constitutional Court, S. Calzolaio, Il cammino delle materie nello Stato regionale. La definizione delle competenze legislative nell'ordinamento costituzionale [The progress of subject-matters within the regional State. The definition of legislative competences in the constitutional order], Torino 2012, esp. p. 186 et seq.

${ }^{45}$ D' Atena, supra note 7, p. 22 et seq., already highlighted, in this regard, the "ductility" of transversal competences, identifying the points of contact with the German konkurrierende Gesetzgebund (Section 72 of the Grundgesetz), which allows the federal
} 
The possibility for the State to exercise this compression carries with it the risk of prejudicing the legislative autonomy of the Regions, which, failing any corrective measures and guarantees, could be arbitrarily limited by the State.

However, the Constitutional Court consistently ruled out this possibility, both acknowledging that regional laws adopted in the exercise of "concurrent" or "residual" powers can take among their goals also those that affect the state exclusive "transversal" competences ${ }^{46}$ and asserting that the exercise of the latter by the State can be considered legitimate in so far as it proves useful to achieve the desired purpose, in accordance with the criteria of reasonableness, congruency and proportionality. This decision cannot be made in a uniform way, but only from time to time, seeking a "flexible balance" in the allocation of powers which ensures the satisfaction of the relevant interests ${ }^{47}$.

This approach repeatedly turned into the verification of compliance with the above limits, as well exemplified by the case law on "competition protection". Thus, in Judgment no. 272/2004, the Constitutional Court after defining the "criteria of proportionality and adequacy" as "essential" to "identify the operative field" of this competence and, "therefore, the legitimacy of its state rules" - held that the rule at issue (on the local public services) violated, in the present case, the above criteria: state intervention, through an "extremely detailed and self-applicative rule", has actually led to "an unlawful compression of regional autonomy" and "is unjustified and unfit to achieve competition protection".

The use of this criterion in some more recent decisions led the Constitutional Court to a different conclusion. In Judgment no. 345/2004, after recalling, once again, the need "to take into account the principles of proportionality and adequacy of the tools used to meet the established purpose", the Court pointed out that the contested state rule (on the purchase of goods and services) does not imply for the Regions "the

legislator, under certain conditions, to affect its relationship with the legislators of the Länder, directing the exercise of its powers to areas reserved for the latter.

${ }^{46}$ With regard to the "protection of the environment" see, among the first decisions, Judgments no. 407/2002, no. 222 and no. 307/2003.

47 See Giuffrè, supra note 4, p. 97. 
use of specific methods, but only the observance of the principles deduced from the state rule", hence the absence of any compression of the regional powers as complained by the applicants. Again, in Judgment no. 200/2012, the Court pointed out that the law at issue (on the liberalization of economic activities) "does not establish rules" but rather introduces "principle provisions which, to be fully enforced, require further regulation by both State and Regions, each within their field of competence", thus excluding the unreasonable compression of regional powers.

The plentiful case law on transversal competences proves their relative ability to maintain a proper balance between pluralism claims and unitary needs, which require the assurance, throughout the whole Country, of minimum standards in terms of rights.

This purpose clearly comes out in the decisions on the LEP ${ }^{48}$, in which the Constitutional Court, while denying the qualification of the same as subject-matters, underlined the functionality of the state competence defined by Section 117, Paragraph 2, letter $m$, to "grant everyone, throughout the whole Country, the enjoyment of guaranteed benefits as an essential part of the rights [...]" (first see the mentioned Judgment no. 282/2002) or, again, to act as a "fundamental tool to ensure the maintenance of an adequate uniformity of treatment in terms of rights for all the people, even in a system characterized by a significantly increased level of regional and local autonomy $[\ldots]^{\prime 49}$. In similar terms, on several occasions, the Constitutional Court ruled on the protection of the environment, confirming the ability of the state competence pursuant to Section 117, Paragraph 2, letter s, to ensure the predetermination of

${ }^{48}$ In this case, the definition of the "internal limit" for the exercise of transversal competences is facilitated by the wording of the constitutional title of competence, which, by referring to "essential" levels, clearly does not prevent the Regions from ensuring higher levels of performance: see G. Scaccia, Il riparto delle funzioni legislative fra Stato e Regioni [The distribution of legislative powers between the State and the Regions], [in:] G. Corso, V. Lopilato (a cura di), Il diritto amministrativo dopo le riforme costituzionali [Administrative Law after constitutional reforms], Milano 2006, p. 27.

${ }^{49}$ See, among others, Judgments no. 88/2003, no. 134/2006, no. 10/2010 and no. $121 / 2014$. 
"uniform standards of protection which are valid throughout the Country and cannot be derogated from in a pejorative way by the Regions" ${ }^{50}$.

The need to ensure these minimum levels allows the Regions to adopt laws that affect the end-result competences reserved to the State, but necessarily in terms of improvement ${ }^{51}$. There is significant constitutional case law which, after establishing the infringement of the minimum standards set by the State, has found regional laws unconstitutional. The same applies to both the case law on environmental protection ${ }^{52}$ and, for its plain protective contribution, to the case law on the LEP, by which the Court declared the unconstitutionality of regional laws that negatively affected, for example, the conditions for access to social benefits. Among its first decisions, Judgment no. 432/2005 declared the unconstitutionality of a Lombard law that granted the right of free circulation on public transport for totally disabled people, but only for Italian citizens, thus violating the state rule that places Italian citizens on the same footing as the legally residing foreigners in their "enjoyment of social welfare benefits and services, including economic ones".

However, the Constitutional Court has also dismissed state appeals for the infringement of transversal competences by regional laws with increased guarantee provisions. For example, with Judgment no. 222/2003 (concerning a Marche law on the possession and trade of exotic animals), the Court ruled out the infringement of the state competence on environmental protection, thus underlining that the regional measures, realized through the exercise of the regional competence on hygiene,

${ }^{50}$ See, among others, Judgments no. 259/2004, no. 232 and no. 336/2005, no. 183/2006 and no. 378/2007.

${ }^{51}$ On the possibility of regional in melius interventions see A. D'Atena, Diritto regionale [Regional Law], Torino 2013, p. 165.

${ }^{52}$ In the field of environmental protection see, among many decisions, Judgments no. 61/2009 (which declared the unconstitutionality of an Aosta Valley provision on waste that introduced less stringent standards than state ones), no. 233/2010 and no. 303/2013 (which declared the unconstitutionality, respectively, of a Friuli-Venezia Giulia and a Campania provision that, unlike state law on the matter, limited the portion of land for wildlife protection), no. 193/2010 (which declared the unconstitutionality of a Piedmont provision that allowed hunting in areas protected by state law) and no. 315/2010 (which declared the unconstitutionality of a Liguria provision that, unlike state provisions on the matter, increased the number of people who can get a hunting license). 
health and veterinary safety (subsumed into the paradigm of "health protection" pursuant to Section 117, Paragraph 3, of the Constitution), "do not weaken but rather strengthen - because of the additional and not substitutive character of regional requirements - state protective measures, so that they cannot affect state objectives in any way".

\subsection{THE „ATTRACTION BY SUBSIDIARITY” OF LEGISLATIVE POWERS}

Overcoming the model of strict separation between state and regional competences, to satisfy unitary interests and competences with specific aims, mainly led to the so-called "attraction by subsidiarity".

This "flexible" tool developed by the Constitutional Court allows for the normal distribution of legislative powers under Section 117 of the Constitution to be departed from, with certain limits, in the presence of unitary needs which are deemed worthy of guarantee.

In this regard, the Constitutional Court stated that "confining state unifying activities to the subject-matters specifically ascribed to state exclusive competence or to establishing the principles of concurrent subject-matters [...] would solidly guarantee regional legislative powers but also extremely undervalue the unitary interests which albeit within constitutional systems which are deeply imbued with institutional pluralism justify, under certain conditions, a derogation from the ordinary distribution of powers" (Judgment no. 303/2003) ${ }^{53}$.

Moving from this premise, the Constitutional Court considered Section 118 of the Constitution as a "factor of flexibility" of the Italian system, that ascribes administrative functions to Municipalities, "unless they are attributed to the Provinces, the Metropolitan Cities and the Regions or to the State, pursuant to the principles of subsidiarity, differentiation and adequacy, to ensure their uniform implementation". In remarking that, whenever there are unitary needs, the administrative functions may be exercised by the State, the Court drew the conclusion that this would necessarily impact on the exercise of legislative functions. The

${ }^{53}$ In support of this thesis, the mentioned Judgment no. 303/2003 refers to the concurrent legislation of the German constitutional system (konkurrierende Gesetzgebung) and to the supremacy clause of the US federal system. 
principle of legality, according to which all the functions which are assumed by subsidiarity must be organized and ruled by the law, "logically excludes that the Regions, each one with its own rules, may regulate state administrative functions and implies that only state law can accomplish such task" (see the above-mentioned Judgment no. 303). Hence, in general terms, whenever implementing the principle of subsidiarity requires switching the administrative functions from the regional to the state level, the State is entitled to use its legislative powers.

The "attraction by subsidiarity", potentially able to entrust the definition of the areas of competence to the State ${ }^{54}$, is bound to negatively impact on regional autonomy, also because this "flexible tool" was allowed for subject-matters which fall within the residual competence pursuant to Section 117, Paragraph 4, of the Constitution ${ }^{55}$.

However, as a guarantee for the Regions - formally equalized with the State but, because of the state unifying attitude, substantially affected by its intervention ${ }^{56}-$, in addition to the exceptional nature of this unifying too ${ }^{57}$, the Court has repeatedly stated that the attraction by subsidiarity of the legislative function can only occur if two conditions are met:

a) Compliance with the criteria of proportionality and reasonableness.

b) Prior implementation of appropriate forms of cooperation with the Regions and, in particular, reaching of an "agreement", either "strong" or "weak", between them and the State. This distinction is made with reference to the outcome of the proceedings: in the first case, failure to reach an agreement "constitutes an insurmountable obstacle to the conclusion of the proceedings"

${ }^{54}$ See E. D'Orlando, Il sistema delle fonti regionali e locali [The system of regional and local sources], [in:] L. Mezzetti (a cura di), La Costituzione delle autonomie. Le riforme del Titolo $V$, Parte II della Costituzione [The Constitution of autonomies. Reforms of Title V, Part II of the Constitution], Napoli 2004, p. 62.

55 See, among others, Judgments no. 214/2006, no. 88/2007 and no. 76/2009 on "tourism".

${ }^{56}$ On the "unifying" attitude of state activities see S. Bartole, Collaborazione e sussidiarietà nel nuovo ordine regionale [Collaboration and subsidiarity in the new regional order], „Le Regioni” 2004, no. 2-3, p. 582.

57 See A. Gentilini, La sussidiarietà appartiene al diritto mite? Alla ricerca di un fondamento giuridico per l'"attrazione in sussidiarietà" [Does subsidiarity belong to soft law? Looking for a legal basis for the "attraction by subsidiarity"], "Giurisprudenza costituzionale" 2008, no. 2, p. 1595 et seq. 
(Judgment no. 6/2004); in the second case, if the State and the Regions, despite their efforts, cannot reach any agreement, the State is entitled to act unilaterally. Initially, the Constitutional Court was in favor of the first alternative (see, as well as the mentioned Judgment no. 6, Judgment no. 383/2005); more recently, the constitutional Judge has accepted that after the unsuccessful experiment of the negotiations, the State is entitled to intervene unilaterally (see Judgment no. 165/2011) ${ }^{58}$.

Once these guarantees have been provided and, therefore, regional autonomy has been granted within certain limits ${ }^{59}$, legislative subsidiarity turns out to be an essential tool to redress the imbalance resulting from an incomplete and incongruous constitutional text ${ }^{60}$ and makes up for the faults of Constitutional Law no. 3/2001 with respect to the creation of a system able to satisfy both unitary and cooperative needs ${ }^{61}$.

\subsection{THE GUARANTEE OF UNITARY INTERESTS IN CONCURRENT COMPETENCES}

The new Section 117 of the Constitution defines the content of concurrent competences stating that, with respect to the subject-matters listed in

58 See A. Concaro, Leale collaborazione e assetto delle competenze fra Stato e Regioni nella giurisprudenza costituzionale [Loyal cooperation and distribution of state and regional competences in constitutional case-law], [in:] P. Cavaleri (a cura di), Temi di diritto regionale nella giurisprudenza costituzionale dopo le riforme [Topics of Regional Law in constitutional case-law after the reforms], Torino 2008, p. 91 et seq.; on the gradual easing of the rules providing for state legislative powers by subsidiarity, which were allegedly implemented by means of the "loyal cooperation" principle through opinions or simple consultation, see C. Mainardis, L'assunzione statale del potere legislativo "in sussidiarietà" [The state implementation of legislative power "by subsidiarity"], in R. Bin, G. Falcon (a cura di), Diritto regionale [Regional Law], Bologna 2012, p. 241-242.

59 In some recent decisions concerning state Law no. 164/2014 (on measures to support economic recovery), the Constitutional Court has proved the application of the set-out criteria and has excluded attraction by subsidiarity (Judgments no. 261/2015 and no. 7/2016).

${ }^{60}$ See P. Cavaleri, Diritto regionale [Regional Law], Padova 2009, p. 129.

${ }^{61}$ On the topic see V. Lopilato, Le funzioni amministrative [Administrative functions], [in:] G. Corso, V. Lopilato (a cura di), supra note 47, p. 279-280. 
Paragraph 3, "legislative powers are vested in the Regions, except for the determination of the fundamental principles, which are reserved to the State".

Pending Constitutional Law no. 3/2001, the letter of the rule, while raising many questions ${ }^{62}$, led to define the limits of the fundamental principles as possible, i.e. in case of adoption by the State of a specific framework law (on the model of the German Rahmengesetze). However, in continuity with the legal system operating before 2001 - which allowed the Regions, lacking specific regulations, to deduce the fundamental principles of each subject-matter from the legislation in force $e^{63}-$, the Constitutional Court stated that "especially in the transition stage from the old to the new division of powers, the regional concurrent legislation must observe the fundamental principles which however result from the state legislation already in force" (Judgment no. 282/2002).

Likewise based on the principle of continuity is the position taken by the Constitutional Court with regard to the adoption of state laws including, in addition to fundamental principles, also "yielding" detailed rules that are bound to lose their effectiveness only when the competent regional law comes into force. This practice, which was allowed in the past to ensure state law effectiveness also in case of regional inertia, brought about an expansion of state legislative powers; this is why, upon the entry into force of Constitutional Law no. 3/2001, there was more support for a thesis that asserted the need to limit state competence only to the determination of fundamental principles ${ }^{64}$.

On this point, the position of the Constitutional Court was initially favorable to the promotion of the new wording of the Section 117, Paragraph 3, of the Constitution, which, compared to the past, "expresses the intent of a clearer distinction between the regional legislative competence $[\ldots]$ and the state one, which is limited to establishing the fundamental principles of the rule" (see the above-mentioned Judgment

${ }^{62}$ R. Bin, Le potestà legislative regionali, dalla Bassanini ad oggi [Regional legislative powers from Bassanini Law to date], "Le Regioni” 2001, no. 4, p. 613 et seq.

${ }^{63}$ On this settlement, see L. Paladin, supra note 12, p. 96.

${ }^{64}$ See G. Falcon, Modello e transizione nel nuovo Titolo $V$ della Parte seconda della Costituzione [Model and transition in the new Title V of Part II of the Constitution], ",Le Regioni" 2001, no. 6, p. 1254. 
no. 282). The following case law sometimes echoed this approach, confirming that "the difference between 'principle' and 'detail' rules consists in the former providing for criteria and purposes and the latter identifying the concrete tools to achieve these purposes" (Judgment no. 341/2010).

With regard to the adoption of "yielding" rules by the State, the case law sometimes initially admitted this possibility ${ }^{65}$, even invoking the "principle of continuity" to protect fundamental rights (on the right to education, see Judgment no. 13/2004); more recently, albeit sometimes admitting this possibility ${ }^{66}$, the Court seems to have moved towards a more restrictive interpretation ${ }^{67}$. However, the uncertainties that still characterize this issue led some scholars to exclude the existence of a unique solution: given that, as acknowledged by the Court itself, "the scope of the fundamental principle must be identified by considering the peculiarities of the subject-matter" (Judgment no. 139/2009), the relationship between principle and detail must be evaluated on a time to time basis, making it impossible to set a clear benchmark ${ }^{68}$.

Finally, with regard to state and regional regulation of the same "subject-matters", it should be noted that the Constitutional Court has sometimes redefined the relationship between State and Regions, overcoming the principle/detail binomial in favor on an integrated system which cannot be subsumed into the traditional categories. For example, with regard to "linguistic minorities", after excluding that failure to list

${ }^{65}$ See, for example, Judgments no. 196/2004 (on amnesty for infringement of building regulations), no. 296 and no. 297/2004 (on local taxes). On the possible adoption of "yielding" rules see also the above-mentioned Judgment no. 303/2003, in which, while agreeing that the reversal of the criteria for distribution of legislative powers and the exhaustive enumeration of state competences "should rule out the possibility of supplementary regulation, by the State, of subject-matters which fall within concurrent legislation", the Court stated that this may occur if it is useful "to ensure the immediate exercise of administrative functions that the State took on to satisfy unitary needs which must be satisfied by all means".

${ }^{66}$ See, for example, Judgment no. 176/2010.

67 See, for example, Judgments no. 156, no. 207, no. 278/2010 and no. 147/2012.

${ }^{68}$ See T. Martines, A. Ruggeri, C. Salazar, Lineamenti di diritto regionale [Regional Law fundamentals], Milano 2012, p. 191; otherwise, A. D'Atena, supra note 50, p. 153-155, who, referring to the decisions quoted in the previous note, affirms the overcoming of the "yielding" rules practice. 
the same into Section 117, Paragraph 2 and 3, of the Constitution allows their inclusion into residual matters pursuant to Paragraph 4, in Judgment no. 159/2009 the Court spoke about "a model of power distribution [...] that does not correspond to the well-known categories defined for all the other subject-matters by Title V, Part II, of the Constitution, both before and after the 2001 constitutional reform". The Court thus defined a model of distribution that, even in the context of a pluralistic system which allows regional guarantee measures, tends to ensure the satisfaction of general interests and, therefore, the "sustainability of a linguistic pluralism' which is eligible for protection" ${ }^{\prime 69}$ through state intervention.

\section{THE SATISFACTION OF UNITARY INTERESTS IN CONSTITUTIONAL REFORM BILLS}

If the model of distribution of legislative power between the State and the Regions as defined by the Section 117 of the Constitution is formally based on the principle of separation, the evolution of constitutional case law contributed to its overcoming ${ }^{70}$, which occurred in practice through the development of the flexible factors offered by the system.

As shown by the constitutional case law on transversal competences, attraction by subsidiarity and concurrent legislation, this evolution became necessary to satisfy the unitary needs which are typical of every pluralistic system. Although this resulted in a less formal equalization of all the constituent entities of the Republic as defined by Section 114, paragraph 1, of the Constitution in favor of a "re-qualification"

${ }^{69}$ R. Toniatti, Pluralismo sostenibile e interesse nazionale all'identità linguistica posti a fondamento di "un nuovo modello di riparto delle competenze" legislative fra Stato e Regioni [Sustainable pluralism and national interest in linguistic identity at the basis of the "new model of distribution of legislative competences" between the State and the Regions], "Le Regioni" 2009, no. 5, p. 1135.

${ }^{70} \mathrm{P}$. Caretti, La Corte e la tutela delle esigenze unitarie: dall'interesse nazionale al principio di sussidiarietà [The Court and the protection of unitary needs: from national interest to the principle of subsidiarity], „Le Regioni” 2004, no. 2-3, esp. p. 381-384, already understood, in the margins of the initial constitutional case law, the overcoming of the formal observance of the principle of separation granted by Section 117 of the Constitution.

${ }^{71} \mathrm{G}$. Rolla, Il difficile equilibrio tra autonomia ed unità nel regionalismo italiano [The 
state role, the case law contribution, if compared to the past, went through the definition of adequate guarantees for regional self-government and, in particular, through the dynamic identification of a point of balance between the unitary needs and the valorization of pluralism.

The indisputable merit of constitutional case law does not exempt us from a final reflection on the need for constitutional legislative measures, aimed, on the one hand, to "correct" the lists under Section 117 of the Constitution - thus overcoming the above-mentioned incongruities and gaps $^{72}$ - but, mostly, on the other hand, to define some locations for any settlement and preventive confrontation between the State and the Regions, which can be useful, while respecting the autonomy of every entity, to adopt the most suitable rules for the satisfaction of the underlying interests ${ }^{73}$.

As for the first aspect, the constitutional review Bill passed by the Italian Parliament in 2005 ("Amendments to Part II of the Constitution"), rejected by referendum in 2006, already provided for a change of the subject-matters lists. Section 39 of the Bill, on the one hand, formally recognized some matters as exclusively regional (among these subjectmatters, "health care and health organization", "school organization" and "local and regional administrative police") and, on the other hand, it brought some of the matters that the 2001 constitutional amendment had included among the concurrent ones back under state exclusive competence (among these subject-matters, "general rules on health protection", "safety at work", "large strategic transport networks", "communications system", "intellectual professions system", "national sports system").

difficult balance between autonomy and unity in Italian regionalism], in G. Rolla (a cura di), La definizione del principio unitario negli ordinamenti decentrati [The definition of the unitary principle in the decentralized orders], Torino 2003, p. 11.

72 Take as an example, once again, "post and telecommunications" and "road traffic".

${ }^{73}$ On this point see R. Bin, Riforma costituzionale e Regioni: ancora troppi equivoci [Constitutional reform and Regions: yet too many misunderstandings], [in:] F. Palermo, S. Parolari (a cura di), Riforma costituzionale e Regioni. Riflessioni a prima lettura sul nuovo Titolo $V$ della Costituzione [Constitutional reform and Regions. First reading reflections on the new Title V of the Constitution], Bolzano/Bozen 2015, esp. p. 11-14. 
The same orientation applied to the Constitutional Bill A.S. 1429 of 8 April 2014 (the so-called "Renzi-Boschi Reform") ${ }^{74}$ which, after several amendments and its approval by both Chambers of the Italian Parliament according to the procedure provided for by Section 138 of the Constitution, was also rejected by voters with a referendum held on December 4th, 2016.

The Bill took measures, among others, regarding Section 117 of the Constitution. In its suggested wording, it corrected the list of exclusive competence subject-matters and attributed to state exclusive competence, among others, the "general provisions on health protection, food safety and job protection and safety", the "general provisions on cultural activities, tourism and sports system", the "national system and coordination of civil protection" and the "strategic infrastructures". The Bill also eliminated the concurrent competences and it re-phrased the residual clause: though it reserved to regional legislative competence "any subject-matter or function that is not expressly reserved to the State", on the one hand, it allowed the State to legislate on matters or functions that were not reserved to it in accordance with the "supremacy clause"75 and, on the other hand, under certain conditions, to delegate to one or more Regions the exercise of legislative powers on subject-matters which fell within the state exclusive competence.

This Bill clarified but did not solve the major problem, that is the potential conflicting nature of every rigid dualistic system which depends on a model of distribution of legislative powers "by subject-matters" rather than relying on the definition of "goals" and "functions". However, this remark enhanced the choice made by the Bill to provide for the socalled "state supremacy clause" to defend unitary needs. This clause allowed the State to legislate on matters or functions that were not reserved to itself "when necessary for the protection of the legal or economic unity of the Republic or the implementation of social and economic programs or reforms having a national interest"76.

74 "Provisions for overcoming equal bicameralism, reducing the number of Members of Parliament, limiting the operating costs of the Institutions, the suppression of Cnel and the amendment of Title V of Part II of the Constitution".

75 See below in the text.

${ }^{76}$ On the amendments to Section 117 of the Constitution proposed by the so-called 


\section{FINAL REMARKS}

After the failure of the reform plans, the need for a constitutional intervention that might bring greater clarity in the allocation of competences is still felt and seems to have been made even stronger by the autonomist claims by some of the Regions. In particular, the consultative referenda on autonomy held in Veneto and Lombardy on 22 October 2017 - with which the voters expressed their appreciation for the start of negotiations with the State in order to obtain special additional forms and conditions of autonomy within the limits of Section 116, Paragraph 3 , of the Constitution - have highlighted the unresolved tensions between the centre and the periphery, which the "differentiation clause" governed by this Section alone does not seem able to solve.

Waiting for further acts of the constitutional legislator, the overcoming of the limits of the lists of subject-matters makes it necessary, as mentioned above, to formalize, also by way of legislation (but to a higher degree than that offered by Law no. 131 of 5 June 2003, so-called "La Loggia Law" implementing Constitutional Law no. 3/2001), suitable confrontation procedures, enhancing the tools of loyal cooperation, also through the formal involvement of the State-Regions Conference. Only such measures will allow, if coupled with end-result competences and operation of the above-mentioned "legislative subsidiarity", to "control" any possible overlapping of competences and, more generally, to ensure the correct functioning of the system ${ }^{77}$, releasing the Constitutional Court from the risk of arbitrariness ${ }^{78}$ and a role of "substitution" that does not belong

\footnotetext{
"Renzi-Boschi Reform" see, among others, U. De Siervo, Una prima lettura del progettato nuovo art. 117 Cost. [A first reading of the newly designed Section 117 of the Constitution], „Rivista AIC" 2016, no. 1, p. 1-9, and G. Scaccia, I tipi di potestà legislativa statale e regionale nella riforma costituzionale [The types of state and regional legislative powers within the constitutional reform ], „Le Istituzioni del federalismo” 2016, no. 1, p. 87 et seq.

77 See L. Vandelli, La Repubblica delle autonomie nella giurisprudenza costituzionale [The Republic of autonomies in constitutional case-law], [in:] A. Pioggia, L. Vandelli (a cura di), La Repubblica delle autonomie nella giurisprudenza costituzionale [The Republic of autonomies in constitutional case-law], Bologna 2006, p. 40 et seq.

${ }^{78}$ On this point, with particular reference to the constitutional formalization of suitable procedural tools aimed at defining the state and regional areas of competence,
} 
to her and that the same Court, as stated by the Judge President a few years ago ${ }^{79}$, did not request nor welcome.
A. D'Atena, Il riparto delle competenze legislative: una complessità da governare [The complex distribution of legislative competences], [in:] A. Di Giovine, A. Mastromarino (a cura di), Il regionalismo italiano in cerca di riforme [Italian regionalism in search of reforms], Milano 2008, p. 170 et seq.
${ }^{79}$ G. Zagrebelsky, La giustizia costituzionale nel 2003. Conferenza stampa del 2 aprile 2004 [Constitutional Justice in 2003. Press Conference of April 2nd, 2004], Roma 2004. 
